\title{
PROTON MAGNETIC RESONANCE SPECTROSCOPY IN CHILDREN WITH FETAL ALCOHOL SPECTRUM DISORDERS
}

\author{
Rita de Cássia Ferreira Gonçalves ${ }^{1}$, Marcio Moacyr Vasconcelos², \\ Letícia Oliveira Faleiros ${ }^{3}$, Luiz Celso Hygino da Cruz Jr. ${ }^{4}$, Romeu Cortes Domingues ${ }^{5}$, \\ Adriana Rocha Brito ${ }^{6}$, Jairo Werner Jr. ${ }^{7}$, Gesmar Volga Haddad Herdy ${ }^{8}$
}

\begin{abstract}
Objective: To analyze the metabolic constitution of brain areas through proton magnetic resonance spectroscopy in children affected with fetal alcohol spectrum disorder compared with normal children. Method: The sample of this case-control study included eight boys with epidemiologic history of in utero exposure to alcohol (median age 13.6 \pm 3.8 years) who were diagnosed with fetal alcohol spectrum disorder, and eight controls (median age 12.1 $\pm 3,4$ years). An $8 \mathrm{~cm}^{3}$ single voxel approach was used, with echo time $30 \mathrm{~ms}$, repetition time $1500 \mathrm{~ms}$, and 128 acquisitions in a 1.5T scanner, and four brain areas were analyzed: anterior cingulate, left frontal lobe, left striatum, and left cerebellar hemisphere. Peaks and ratios of metabolites $\mathrm{N}$-acetylaspartate, choline, creatine, and myo-inositol were measured. Results: Children with fetal alcohol spectrum disorder showed a decrease in choline/creatine ratio $(p=0.020)$ in left striatum and an increase in myo-inositol/creatine ratio $(p=0.048)$ in left cerebellum compared with controls. There was no statistically significant difference in all peaks and ratios from the anterior cingulate and frontal lobe between the two groups. Conclusion: This study found evidence that the left striatum and left cerebellum are affected by intrauterine exposure to alcohol. Additional studies with larger samples are necessary to expand our knowledge of the effects of fetal exposure to alcohol.
\end{abstract}

KEY WORDS: fetal alcohol syndrome, alcohol-induced disorders of the nervous system, ethanol, fetal development, magnetic resonance spectroscopy.

\section{Espectroscopia por ressonância magnética de prótons em crianças com transtornos do espectro alcoólico fetal}

Resumo - Objetivo: Analisar a composição metabólica de áreas encefálicas através da espectroscopia de prótons por ressonância magnética em crianças com transtornos do espectro alcoólico fetal e crianças normais. Método: A amostra deste estudo de casos-controles incluiu 8 meninos com história epidemiológica de exposição fetal ao álcool (idade mediana 13,6 633,8 anos), diagnosticados com transtorno do espectro alcoólico fetal, e 8 controles (idade mediana 12,1 $\pm 3,4$ anos). Utilizou-se voxel único de $8 \mathrm{~cm}^{3}$, tempo de eco $30 \mathrm{~ms}$, tempo de repetição 1.500 ms, 128 aquisições, em scanner de 1,5T para as seguintes áreas: cíngulo anterior, lobo frontal esquerdo, estriado esquerdo e hemisfério cerebelar esquerdo. Estudaram-se os picos e as razões dos metabólitos $\mathrm{N}$-acetilaspartato, colina, creatina e o mio-inositol. Resultados: As crianças acometidas apresentaram diminuição da razão colina/creatina $(\mathrm{p}=0,020)$ no estriado esquerdo, e aumento da razão mio-inositol/creatina $(p=0,048)$ no cerebelo esquerdo. Não houve diferença estatisticamente significativa nos valores encontrados no cíngulo anterior e lobo frontal entre os dois grupos. Conclusão: Este estudo encontrou evidências de que 0 estriado e o cerebelo esquerdos são acometidos pela exposição intra-uterina ao álcool. Estudos adicionais com amostras maiores são essenciais para expandir nosso conhecimento dos efeitos da exposição fetal ao álcool.

PALAVRAS-CHAVE: síndrome alcoólica fetal, transtornos do sistema nervoso induzidos por álcool, etanol, desenvolvimento fetal, espectroscopia de ressonância magnética.

\footnotetext{
Universidade Federal Fluminense (UFF) and Multi-Imagem, Niterói and Rio de Janeiro RJ, Brazil: 'MD, MSc in Pediatrics, UFF; ${ }^{2}$ PhD, Associate Professor of Pediatrics, UFF; ${ }^{3}$ Medical Intern, UFF; ${ }^{4} \mathrm{MD}$, Radiologist, Multi-Imagem; ${ }^{5} \mathrm{MD}$, Radiologist and Medical Director, Multi-Imagem; ${ }^{6} \mathrm{MD}, \mathrm{MSc}$ in Pediatrics, Assistant Professor of Pediatrics, UFF; ${ }^{7}$ MD, PhD, Associate Professor of Child Psychiatry, UFF; ${ }^{8} \mathrm{MD}$, PhD, Full Professor of Pediatrics, UFF.
}

Received 23 October 2008, received in final form 12 December 2008. Accepted 7 March 2009.

Dra. Rita de Cássia Ferreira Gonçalves - Avenida Ari Parreiras 655 / apto. 1005 - 24230-321 Niterói RJ - Brasil. E-mail: rcgonc@hotmail.com 
The association between alcohol use during pregnancy and congenital malformations was described by Lemoine in 1968', who established the first diagnostic criteria of what would become known as the fetal alcohol syndrome (FAS) ${ }^{2}$. Clinical signs observed by Lemoine et al.' and later classified by Jones et al. ${ }^{2}$ continue to underlie the identification of affected patients, that is, FAS diagnosis requires a positive maternal history of alcohol use during pregnancy plus the fulfillment of three requisites: a characteristic pattern of facial anomalies (short palpebral fissures, smooth philtrum, thin upper lip, epicanthal fold, flat nasal bridge, malar hypoplasia); evidence of prenatal and postnatal growth retardation, including microcephaly and low birth weight; and abnormalities in development of the central nervous system, which lead to electroencephalographic changes, psychiatric disorders, intellectual disorders, and difficulties in social adaptation ${ }^{3}$. In addition to these features that define the syndrome, there may also be limb abnormalities, eye findings, clef palate, and congenital heart defects ${ }^{4}$.

Additional suggestions were made to improve the classification system of alcohol fetal effects, the most important of which was a review of diagnostic criteria by the Institute of Medicine 5 . When a specific patient does not fulfill all diagnostic criteria of FAS, one may utilize terms such as partial FAS, alcohol-related birth defects (ARBD), or alcohol-related neurodevelopmental disorder (ARND). Finally, the different combinations of clinical abnormalities and their respective diagnostic labels are clustered under the comprehensive term fetal alcohol spectrum disorders (FASD) $)^{3}$.

FAS incidence and prevalence have not been clearly defined. There is an estimate of the worldwide incidence, in which FAS would affect 1.9 case/1000 live births and the ARBD incidence would be 1 case $/ 300$ live births ${ }^{4}$. However, these data depend on cultural and social factors within each population regarding alcohol use by women, so that the actual rates may be at least tenfold increased in high risk populations. In addition, FASD incidence rate may be extremely underestimated due to health workers' lack of knowledge ${ }^{6-8}$. It has been reported that at least $50 \%$ of Canadian and American women drink socially, and as half of all pregnancies are not planned, approximately $25 \%$ of newborns may have been exposed to alcohol in utero ${ }^{9-10}$. According to the Centers for Disease Control, $3-5 \%$ of women continue to use alcohol during pregnancy, and this use is often heavy, such as more than five drinks per event and frequently several times a week ${ }^{11,12}$.

A study from Brazil analyzed a sample of 445 post-delivery women that were admitted to a philanthropic hospital in São Paulo ${ }^{13}$. Overall, 33.7\% of all patients used alcoholic beverages during pregnancy, while $17.8 \%$ did so throughout pregnancy and $15.9 \%$ used alcohol until preg- nancy was detected. In this group, pregnancy diagnosis occurred on average at gestational age 9.6 weeks.

Certain risk factors are associated with an increased likelihood of malformations, including maternal age above 30 years, non-white race, low socioeconomic class, another child with FAS or ARBD, concurrent use of other drugs, family violence, sexual abuse, psychiatric disorders, a reduced number of medical visits during prenatal care, and an increased number of pregnancies ${ }^{14,15}$.

FAS etiologic mechanisms are not completely understood. It is well known that all children are not affected with a similar pattern and severity, as fetal susceptibility to alcohol is influenced by the amount of alcohol intake, timing of exposure, nutritional status, and maternal and fetal metabolism capacity ${ }^{16}$. However, the pathogenesis of ethanol-induced disorders in development of central nervous system seems to be primarily related to the neuronal proliferation, migration, and organizational events, including impairments in the neurotransmitter systems and their receptors, synthesis, and catabolism ${ }^{4,17}$.

The issue of alcohol use during pregnancy is not only a medical problem, as this association contains several social implications, such as an increased risk of negligence and abuse, as well as an environment that is inadequate for child development, resulting in mortality risk increase ${ }^{12}$. Another significant social implication is due to alcoholinduced mental impairment with intellectual disability, restricted occupational choices, prolonged dependence, and a variety of behavioral problems. Therefore, the overwhelming effects of fetal exposure to alcohol persist well into adulthood, leading to severe limitations in the quality of life of affected patients and their families ${ }^{18,19}$.

In the present time, 40 years after its first description, although several lines of research were developed, FAS continues to be defined upon purely clinical grounds, as there is yet no laboratory or radiologic marker that contributes to diagnosis. Except for the most severely affected cases, recognition of a child that was exposed to alcohol in utero is extremely difficult ${ }^{14,20}$. This difficulty often hinders an early diagnosis, which otherwise would act as a protecting factor, allowing for a better quality of life, inasmuch as it would offer a more stable environment and provide the affected individual with eligibility for specific rehabilitation programs ${ }^{19,20}$.

Proton magnetic resonance spectroscopy (1H-MRS) was approved by the U.S. Food and Drug Administration (FDA) for clinical application in 1995. Since then, it has established itself as an useful non-invasive tool to obtain cerebral biochemical data in vivo. It offers the possibility of early detection of pathologic processes that have not yet produced structural abnormalities. Depending on the sequence parameters chosen to obtain spectra, 1H-MRS measures quantitatively the following metabolites: $\mathrm{N}$ - 

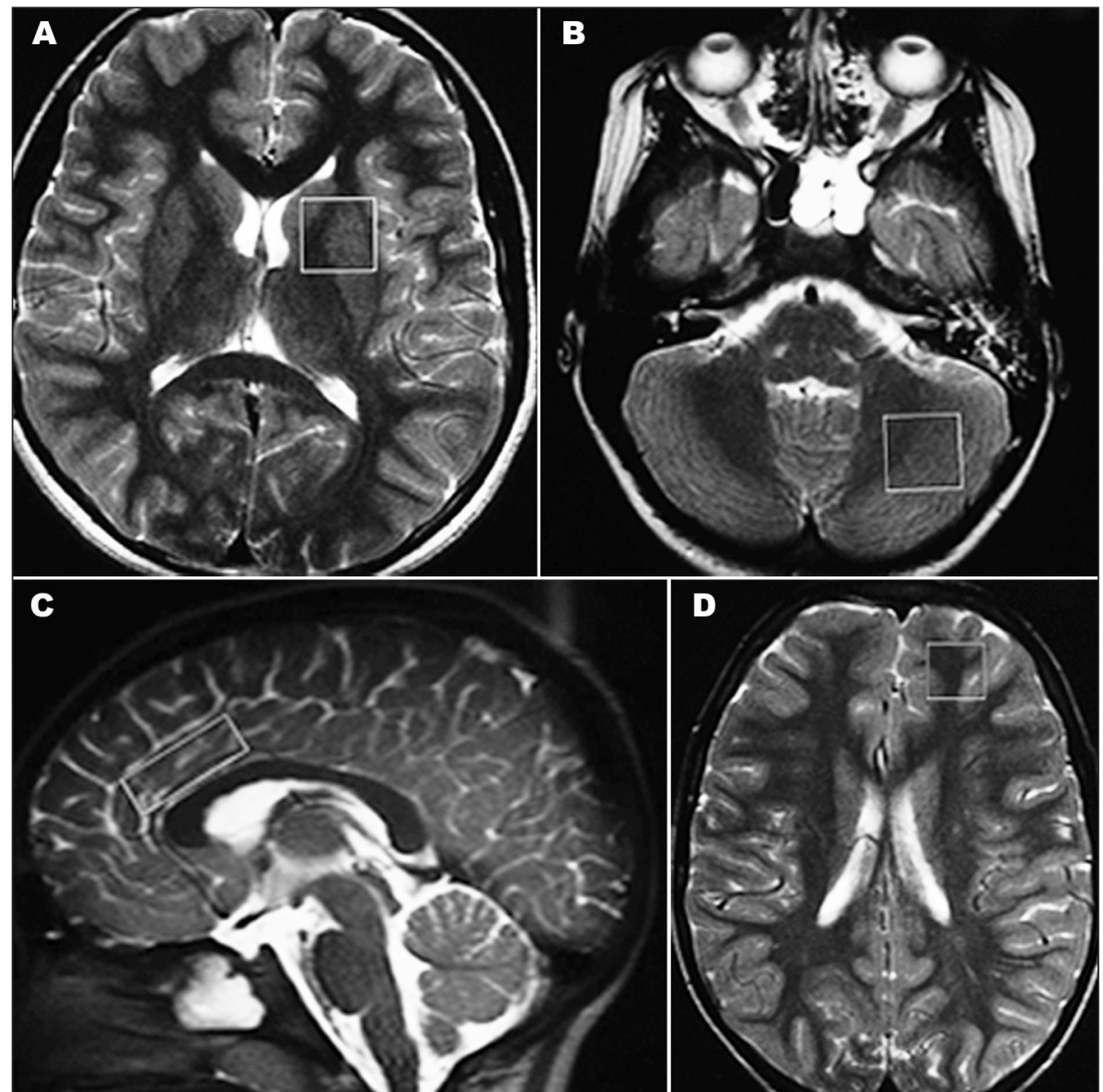

Figure. Localization of four voxels for proton magnetic resonance spectroscopy. [A] Left striatum; [B] Left cerebellar hemisphere; $[C]$ Anterior cingulate; $[D]$ Left frontal lobe. acetylaspartate (NAA), choline (Cho), creatine and phosphocreatine ( $\mathrm{Cr}$ ), myo-inositol (MI), glutamate, glutamine, lactate, lipids, and alanine ${ }^{21}$.

This study purpose is to analyze brain metabolites through $1 \mathrm{H}-\mathrm{MRS}$ in children and adolescents diagnosed with FASD, and to compare their results with age-, gender-, and socioeconomic class-matched controls.

\section{METHOD}

This is a case-control study that recruited patients from December 2005 through May 2007. Cases were recruited in the Child Neurology Clinic at Hospital Universitário Antônio Pedro (three cases); in the Genetics Clinic at Instituto Fernandes Figueira (two cases); and in the Escola de Educação Especial da Associação Pestalozzi de Niterói (three cases). Controls were recruited from the local public school system, and four of them had previously taken part in a research on autism and $1 \mathrm{H}-\mathrm{MRS}^{22}$.

Research protocol was approved by the Research Ethics Committee from Hospital Universitário Antônio Pedro-Universidade Federal Fluminense, under CEP identification number CMM/HUAP-148/2004, as well as by the Ethics Committee from Instituto Fernandes Figueira-IFF/FIOCRUZ, under the
Ethics in Research National Committee identification number 0014.0.008.000-06.

Any given patient with FASD was accepted in the study only after fulfilling the following inclusion criteria: male gender; age between 8 and 17.9 years; right handedness; diagnosis of FASD established by a geneticist or child neurologist according to the Institute of Medicine criteria ${ }^{5}$; reading and signature of informed consent by parents or legal guardians. Exclusion criteria included: maternal history of other drug use during pregnancy; acute perinatal asphyxia; congenital infection; any disease of the central nervous system; use of dental braces or any other metallic device. Controls consisted of children and adolescents that were healthy, right-handed, with good school performance, and free of any medication.

Every subject had a complete history and physical and neurologic exams in the intake visit. All magnetic resonance studies were performed in a single 1.5 Tesla scanner (Symphony Maestro Class, Siemens, Germany). All subjects underwent a standardized imaging protocol, which included T2-weighted images on axial, sagittal, and coronal plans.

In order to acquire 1H-MRS, magnetic field homogenization was performed through shimming on the water signal of the vol- 
Table 1. Statistical analysis of NAA/Cr ratio between cases and controls.

\begin{tabular}{|c|c|c|c|c|}
\hline \multirow[b]{2}{*}{ Voxel localization } & \multicolumn{4}{|c|}{ NAA/Creatine ratio } \\
\hline & $\mathrm{m}$ & SD & range & $\mathrm{P}$ \\
\hline \multicolumn{5}{|l|}{ Anterior cingulate } \\
\hline Cases & 1.67 & 0.17 & $1.42-1.92$ & 0.278 \\
\hline Controls & 1.69 & 0.10 & $1.64-1.90$ & \\
\hline \multicolumn{5}{|l|}{ Left frontal lobe } \\
\hline Cases & 2.08 & 0.12 & $1.87-2.23$ & 0.225 \\
\hline Controls & 1.89 & 0.17 & $1.76-2.23$ & \\
\hline \multicolumn{5}{|l|}{ Left striatum } \\
\hline Cases & 1.61 & 0.27 & $1.19-1.96$ & 0.652 \\
\hline Controls & 1.52 & 0.28 & $1.23-2.11$ & \\
\hline \multicolumn{5}{|l|}{ Left cerebellum } \\
\hline Cases & 1.44 & 0.23 & $1.17-1.90$ & 0.511 \\
\hline Controls & 1.35 & 0.20 & $1.22-1.82$ & \\
\hline
\end{tabular}

SD: standard deviation; m: median; $\mathrm{p}$ : significance in ANOVA test.

Table 2. Statistical analysis of NAA/Cho ratio between cases and controls.

\begin{tabular}{|c|c|c|c|c|}
\hline \multirow[b]{2}{*}{ Voxel localization } & \multicolumn{4}{|c|}{ NAA/Choline ratio } \\
\hline & $\mathrm{m}$ & SD & range & $\mathrm{p}$ \\
\hline \multicolumn{5}{|l|}{ Anterior cingulate } \\
\hline Cases & 2.29 & 0.39 & $1.74-3.05$ & 0.895 \\
\hline Controls & 2.31 & 0.26 & $1.99-2.74$ & \\
\hline \multicolumn{5}{|l|}{ Left frontal lobe } \\
\hline Cases & 2.67 & 0.24 & $2.27-3.09$ & 0.514 \\
\hline Controls & 2.51 & 0.40 & $2.01-3.25$ & \\
\hline \multicolumn{5}{|l|}{ Left striatum } \\
\hline Cases & 2.58 & 0.32 & $2.06-2.99$ & 0.116 \\
\hline Controls & 2.20 & 0.33 & $1.65-2.67$ & \\
\hline \multicolumn{5}{|l|}{ Left cerebellum } \\
\hline Cases & 2.16 & 0.42 & $1.83-3.19$ & 0.148 \\
\hline Controls & 1.90 & 0.33 & $1.67-2.62$ & \\
\hline
\end{tabular}

SD: standard deviation; m: median; $\mathrm{p}$ : significance in ANOVA test.

Table 3. Statistical analysis of Cho/Cr ratio between cases and controls.

\begin{tabular}{|c|c|c|c|c|}
\hline \multirow[b]{2}{*}{ Voxel localization } & \multicolumn{4}{|c|}{ Choline/Creatine ratio } \\
\hline & $\mathrm{m}$ & SD & range & $P$ \\
\hline \multicolumn{5}{|l|}{ Anterior cingulate } \\
\hline Cases & 0.73 & 0.08 & $0.61-0.83$ & 0.552 \\
\hline Controls & 0.75 & 0.06 & $0.66-0.83$ & \\
\hline \multicolumn{5}{|l|}{ Left frontal lobe } \\
\hline Cases & 0.77 & 0.04 & $0.71-0.83$ & $0.916^{*}$ \\
\hline Controls & 0.76 & 0.10 & $0.63-0.95$ & \\
\hline \multicolumn{5}{|l|}{ Left striatum } \\
\hline Cases & 0.60 & 0.04 & $0.55-0.66$ & $0.020 *$ \\
\hline Controls & 0.72 & 0.10 & $0.59-0.87$ & \\
\hline \multicolumn{5}{|l|}{ Left cerebellum } \\
\hline Cases & 0.66 & 0.05 & $0.55-0.69$ & 0.064 \\
\hline Controls & 0.70 & 0.06 & $0.61-0.79$ & \\
\hline
\end{tabular}

*significance do $\mathrm{p}$ in Kruskal-Wallis test; SD: standard deviation; m: median; $\mathrm{p}$ : significance in ANOVA test. 
Table 4. Statistical analysis of $\mathrm{MI} / \mathrm{Cr}$ ratio between cases and controls.

\begin{tabular}{|c|c|c|c|c|}
\hline \multirow[b]{2}{*}{ Voxel localization } & \multicolumn{4}{|c|}{ Myo-inositol/Creatine ratio } \\
\hline & $\mathrm{m}$ & SD & range & $P$ \\
\hline \multicolumn{5}{|l|}{ Anterior cingulate } \\
\hline Cases & 0.56 & 0.08 & $0.44-0.65$ & 0.150 \\
\hline Controls & 0.62 & 0.06 & $0.49-0.66$ & \\
\hline \multicolumn{5}{|l|}{ Left frontal lobe } \\
\hline Cases & 0.53 & 0.13 & $0.21-0.57$ & 0.239 \\
\hline Controls & 0.51 & 0.07 & $0.45-0.64$ & \\
\hline \multicolumn{5}{|l|}{ Left striatum } \\
\hline Cases & 0.34 & 0.13 & $0.11-0.54$ & 0.399 \\
\hline Controls & 0.33 & 0.23 & $0.22-0.83$ & \\
\hline \multicolumn{5}{|l|}{ Left cerebellum } \\
\hline Cases & 0.55 & 0.25 & $0.43-1.21$ & 0.048 \\
\hline Controls & 0.42 & 0.17 & $0.06-0.55$ & \\
\hline
\end{tabular}

SD: standard deviation; $\mathrm{m}$ : median; $\mathrm{p}$ : significance in ANOVA test.

Table 5. Comparison between previous studies and the current study on proton magnetic resonance spectroscopy of children and adolescents with fetal alcohol spectrum disorders

\begin{tabular}{|c|c|c|c|c|c|c|c|}
\hline \multirow{2}{*}{$\begin{array}{l}\text { First } \\
\text { author }\end{array}$} & \multicolumn{2}{|c|}{ Population } & \multirow[b]{2}{*}{ Regions of Interest } & \multirow[b]{2}{*}{ Voxel } & \multirow[b]{2}{*}{ TE } & \multirow[b]{2}{*}{$\mathrm{TR}$} & \multirow[b]{2}{*}{ Findings } \\
\hline & $\mathrm{n}$ & Age & & & & & \\
\hline $\begin{array}{l}\text { Astley } \\
\text { USA } \\
(1995)^{28}\end{array}$ & $\begin{array}{l}20 \text { primates } \\
20 \text { controls }\end{array}$ & $2.4-4.1 \mathrm{yr}^{*}$ & $\begin{array}{l}\text { Thalamus, internal capsule, basal } \\
\text { ganglia, contiguous white matter }\end{array}$ & $\begin{array}{c}\mathrm{SV} \\
3.4 \mathrm{~cm}^{3}\end{array}$ & 136 & 2000 & $\uparrow \mathrm{Cho} / \mathrm{Cr}$ \\
\hline $\begin{array}{l}\text { Cortese } \\
\text { USA } \\
(2006)^{29}\end{array}$ & $\begin{array}{l}7 \text { with FAS } \\
2 \text { with ARBD } \\
4 \text { controls }\end{array}$ & $9-12 \mathrm{yr}$. & Left and right caudate nuclei & $\begin{array}{c}\mathrm{MV} \\
0.8 \mathrm{~cm}^{3}\end{array}$ & 280 & 2300 & $\begin{array}{l}\uparrow N A A / C r \text { in } L \text { and } R \text { caudate } \\
\text { in children with FAS } \\
\uparrow N A A \text { peak and ff NAA/Cr } \\
\text { in children with ARBD }\end{array}$ \\
\hline $\begin{array}{l}\text { Fagerlund } \\
\text { Finland } \\
(2006)^{30}\end{array}$ & $\begin{array}{l}10 \text { with } \\
\text { FASD } \\
10 \text { controls }\end{array}$ & $14-21$ yr. & $\begin{array}{l}\text { Temporal, parietal, and frontal } \\
\text { cortex; corpus callosum; frontal } \\
\text { white matter; basal ganglia; hip- } \\
\text { pocampus; cerebellar vermis and } \\
\text { hemispheres; dentate nuclei }\end{array}$ & $\begin{array}{c}\mathrm{MV} \\
0.75 \mathrm{~cm}^{3}\end{array}$ & 288 & 1500 & $\begin{array}{l}\mathrm{NAA} / \mathrm{Cr} \text { and/or NAA/Cho } \\
\text { in all areas }\end{array}$ \\
\hline $\begin{array}{l}\text { Current } \\
\text { study } \\
\text { Brazil } \\
\text { (2008) }\end{array}$ & $\begin{array}{l}8 \text { cases } \\
8 \text { controls }\end{array}$ & $8-18 \mathrm{yr}$. & $\begin{array}{l}\text { Left frontal lobe; left anterior cin- } \\
\text { gulate; left striatum; and left cere- } \\
\text { bellar hemisphere }\end{array}$ & $\begin{array}{c}\mathrm{SV} \\
8 \mathrm{~cm} 3\end{array}$ & 30 & 1500 & $\begin{array}{l}\downarrow \mathrm{Cho} / \mathrm{Cr} \text { in left striatum } \\
\uparrow \mathrm{MI} / \mathrm{Cr} \text { in left cerebellum }\end{array}$ \\
\hline
\end{tabular}

*Age range equivalent to adolescence in human beings. ARBD: alcohol-related birth defects; Cho: choline; Cr: creatine; FAS: fetal alcohol syndrome; FASD: fetal alcohol spectrum disorders; L: left; MI: myo-inositol; MV: multivoxel; NAA: N-acetylaspartate; R: right; SV: single voxel; TE: echo time; TR: repetition time; $\uparrow:$ increased; $\downarrow$ : decreased.

ume of interest to a line width of about $8 \mathrm{~Hz}$. The single-voxel procedure applied a spin-echo sequence (TR/TE=1,500/30 ms, averages $=3$, flip angle $=90^{\circ}, 128$ acquisitions) with point-resolved spectroscopy (PRESS) technique. A single neuroradiologist outlined four single voxels of $8 \mathrm{~cm}^{3}(2.0 \times 2.0 \times 2.0 \mathrm{~cm})$ in the following regions of interest: left frontal lobe; left anterior cingulate; left striatum; and left cerebellar hemisphere (Figure). The four brain areas were chosen according to previous studies that defined basal ganglia, cerebellum, and cerebral white matter as being particular susceptible to alcohol effects in utero ${ }^{23,24}$. The voxels were positioned excluding contamination of signal from the skull and subcutaneous fat. Preparation scans were used and water saturation applied. Each region of interest was processed successively. Average scanning time for each patient was 20 minutes. Peaks of metabolites NAA, $\mathrm{Cho}, \mathrm{Cr}$, and $\mathrm{Ml}$, and ratios $\mathrm{NAA} / \mathrm{Cr}$, NAA/Cho, $\mathrm{Cho} / \mathrm{Cr}$, and $\mathrm{Ml} / \mathrm{Cr}$ were measured.

Data from $1 \mathrm{H}-\mathrm{MRS}$ of cases and controls were collected and analyzed through software Epilnfo 2000, version 3.3.2. Analysis of variance (ANOVA) test was used during statistical assessment of the differences between cases and controls regarding metab- 
olite peaks and ratios. A specific difference was considered to be statistically significant when $p$ value was equal to or less than 0.05 . When the results of Bartlett test showed a $p<0.05$, suggesting that ANOVA test was inappropriate, statistical significance was assessed according to Kruskal-Wallis test. Both radiologists that read neuroimaging tests were kept "blinded" to subjects diagnosis throughout the study, so that bias was avoided.

\section{RESULTS}

Study sample is composed of eight cases and eight controls. Median age \pm standard deviation of cases was $13.6 \pm 3.8$ years, while that of controls was $12.1 \pm 3.4$ years. There was no significant age difference between the two groups ( $p=0.99$ ). All subjects were male and right-handed. Among cases, one patient only received psychoactive medications at the time of neuroimaging test, including carbamazepine, lithium carbonate, and periciazine (a phenotiazine). None of the controls used any regular medication.

There was no significant difference in NAA and $\mathrm{Cr}$ peaks or in NAA/Cr (Table 1) and NAA/Cho ratios (Table 2 ) in all four regions of interest. A statistically significant decrease was found in $\mathrm{Cho} / \mathrm{Cr}$ ratio $(p=0.020)$ in left striatum (Table 3). There was a trend toward elevation of MI peak in left cerebellum ( $p=0.087)$, as well as for decrease in Cho peak in left striatum $(p=0.058)$ and in Cho/Cr ratio in left cerebellum $(p=0.064)$ in cases compared with controls, however these findings did not reach statistical significance. Finally, there was a statistically significant increase in $\mathrm{Ml} / \mathrm{Cr}$ ratio ( $\mathrm{p}=0.048)$ in left cerebellum of cases versus controls (Table 4).

\section{DISCUSSION}

Alcohol teratogenic effects were extensively studied by means of structural magnetic resonance ${ }^{23,25-27}$, so that brain regions most vulnerable to in utero alcohol exposure were defined. Mattson et al. ${ }^{23}$ utilized MR images to show significant reduction in hemispheric volume, basal ganglia, and diencephalon in 6 children with FAS versus 7 controls. In a subsequent study ${ }^{25}$, those authors concluded that areas such as basal ganglia, corpus callosum, and parts of cerebellum are likely to be particularly susceptible to alcohol teratogenesis.

Sowell et al. ${ }^{26}$ mapped patterns of asymmetry in cortical gray matter of teenagers that had sustained heavy prenatal exposure to alcohol. They performed brain MRI of 21 8-22 year-old subjects with history of prenatal exposure and 83 healthy controls aged 8-25 years. Asymmetry was found, as well as a decrease in gray matter density in inferior and posterior temporal lobe regions, a finding that was more prominent in left hemisphere than in the right one.

Riley et al. ${ }^{27}$ reported that one of the most consistent findings in MR imaging analysis is a reduction in the cranial vault size, an effect that appears to be much more evident in individuals with FAS than in those without facial dysmorphology. They suggested that the cerebellum is a particularly sensitive structure to prenatal alcohol exposure.

Although 1H-MRS has been approved for diagnostic use more than a decade ago, there are few published scientific studies applying it for patients exposed to alcohol in utero. Currently, there are only three pertinent studies $^{28-30}$, shown in Table 5. All three studies differ regarding voxel localization, which makes it more difficult to compare results. In addition, those studies used different species (non-human primates and human beings) and markedly distinct technical parameters. Therefore, their results may appear to be conflicting.

Astley et al. ${ }^{28}$ obtained MRI and 1H-MRS in a group of 20 pig-tailed macaque primates that underwent experimentally induced and controlled fetal exposure to alcohol, in comparison with a control group of equal size. Neuroimaging was performed while all animals were 2.44.1 year-old, which would be equivalent to human adolescence, in order to assess long-term effects of alcohol. Their data showed an increased $\mathrm{Cho} / \mathrm{Cr}$ ratio $(\mathrm{p}=0.006)$, in the absence of cerebral structural damage. Cerebral areas analyzed included the thalamus, internal capsule, basal ganglia, and adjacent white matter, however the authors did not specify which area or areas displayed an increased Cho/Cr ratio.

Cortese et al. ${ }^{29}$ studied the caudate nucleus through $1 \mathrm{H}-\mathrm{MRS}$ in seven children with FAS, two children with alcohol fetal effects, and four control children, with an age range of 9-12 years and including both genders. They found an elevated NAA/Cr ratio in left and right caudate nuclei ( $p=0.04$ and 0.03 , respectively) in FAS affected children compared with controls. There was also an increase in NAA peak $(p=0.01)$ in right caudate nucleus and in NAA/Cr ratio $(p=0.03)$ in left caudate nucleus in children with alcohol fetal effects versus controls. The authors suggest that, although neuronal dysfunction is traditionally associated with a decrease in NAA absolute concentration, the increase in NAA could also reflect functional abnormalities and cognitive deficits ${ }^{29}$.

Fagerlund et al. ${ }^{30}$ performed $1 \mathrm{H}-\mathrm{MRS}$ in 10 children with FASD and 10 control children, and subjects were paired for gender, handedness, decimal age, body mass index, and head circumference. All subjects were from 1421 year-old, and there were 18 girls and two boys. Their results included a decrease in NAA/Cr and/or NAA/Cho ratios in all assessed areas, and these findings were interpreted as suggestive of long-standing or permanent biochemical changes in response to prenatal exposure to alcohol. Based upon the presumption that glial cells may be a primary target of alcohol neurotoxicity, those authors suggested that future studies should utilize a short echo time to study MI alterations. In addition, they hypothesized 
that behavioral and cognitive dysfunction in FASD subjects may occur as a consequence of failed astrocytic function ${ }^{30}$.

The current study found a trend toward MI peak elevation in left cerebellum of cases versus controls $(p=0.087$ ) and a statistically significant increase in $\mathrm{Ml} / \mathrm{Cr}$ ratio in left cerebellum of cases compared with controls $(p=0.048)$. MI is a glial marker ${ }^{31}$, and its increase in a region that is known to be a target of alcohol-induced damage in the developing central nervous system, such as the cerebellum ${ }^{23,27}$, might constitute a marker of alcohol neurotoxicity in utero. In addition, a significant decrease was found in Cho/ $\mathrm{Cr}$ ratio $(\mathrm{p}=0.02)$ in left striatum of cases versus controls, which may reflect diminished turnover of cell membranes due to cellular proliferation impairment, leading to a decreased Cho concentration.

To the best of our knowledge, this is the first study that applied a short echo time to perform $1 \mathrm{H}-\mathrm{MRS}$ in FASD affected children, and our finding of an increased $\mathrm{MI} / \mathrm{Cr}$ in left cerebellar hemisphere of cases lends support to the reasoning by Fagerlund et al. ${ }^{30}$.

Another relevant technical issue is related to the choice between single voxel or multivoxel. Among the three previous studies, two of them used a multivoxel approach $^{29,30}$, aiming to assess several components of a lesion in a specific time and, therefore, to show the metabolic abnormality extent ${ }^{31}$. In the present study, a decision was made to sequentially use single voxels in different regions. Astley et al. ${ }^{28}$ also employed a single voxel technique. Currently, this is the most frequently used $1 \mathrm{H}$-MRS technique, as it is easier to obtain and it offers a more effective water and fat suppression ${ }^{31}$.

As the central nervous system is the primary focus of permanent damage in FAS, with long-standing loss in quality of life of affected individuals, it is hoped that $1 \mathrm{H}-\mathrm{MRS}$ may become an important tool to clarify alcohol noxious effects, even in the absence of structural lesions. 1H-MRS may also be able to assess integrity of neuronal and glial markers ${ }^{29}$. Nevertheless, the increased 1H-MRS sensitivity is counteracted by its decreased specificity, as similar changes in cerebral metabolites may be found in various central nervous system disorders. For example, MI elevation was also described in the frontal lobe white matter of diabetic patients with and without major depression ${ }^{32}$.

A few comments on this study limitations are in order. IQ tests were unavailable at the time of research, and this obstacle reduced characterization of cases and controls and may have added significant cognitive differences among the subjects. The small sample size $(n=16)$ decreases statistical power of the research data. Finally, one of the cases was receiving pharmacologic therapy at the time of brain neuroimaging, which theoretically may have interfered with his $1 \mathrm{H}-\mathrm{MRS}$ results.

In summary, compared with age-, gender-, and socio- economic class-matched controls, children and adolescents with FASD showed at $1 \mathrm{H}-\mathrm{MRS}$ a statistically significant decrease in $\mathrm{Cho} / \mathrm{Cr}$ ratio $(\mathrm{p}=0.020)$ in left striatum, as well as an increase in $\mathrm{Ml} / \mathrm{Cr}$ ratio ( $p=0.048$ ) in left cerebellar hemisphere. These findings suggest that significant intrauterine exposure to alcohol may impair left striatum and left cerebellum functioning. Additional studies, including larger samples, are likely to increase our knowledge of the neuroradiologic findings in children that sustained intrauterine exposure to alcohol.

\section{REFERENCES}

1. Lemoine P, Harousseau H, Borteyru JP, Menuet JC. Les enfants de parents alcooliques. Anomalies observées: a propos de 127 cas. Ouest Med 1968;25:476-482.

2. Jones KL, Smith DW, Ulleland CN, Streissguth P. Pattern of malformation in offspring of chronic alcoholic mothers. Lancet 1973;1:1267-1271.

3. Manning MA, Hoyme HE. Fetal alcohol spectrum disorders: a practical clinical approach to diagnosis. Neurosci Biobehav Rev 2007;31:230-238.

4. Volpe JJ. Teratogenic effects of drugs and passive addiction. In: Volpe JJ. Neurology of the newborn. $4^{\text {th }}$ edition. Philadelphia: W. B. Saunders, 2001:859-898.

5. Hoyme E, May PA, Kalberg WO, et al. A practical clinical approach to diagnosis of fetal alcohol spectrum disorders: clarification of the 1996 institute of medicine criteria. Pediatrics 2005;115:39-47.

6. Elgen I, Bruaroy S, Laegreid LM. Lack of recognition and complexity of fetal alcohol neuroimpairments. Acta Paediatr 2007;96:237-241.

7. Gahagan S, Sharpe TT, Brimacombe M, et al. Pediatricians' knowledge, training, and experience in the care of children with fetal alcohol syndrome. Pediatrics 2006;118:657-668.

8. Jones KL, Robinson LK, Bakhireva LN, et al. Accuracy of the diagnosis of physical features of fetal alcohol syndrome by pediatricians after specialized training. Pediatrics 2006; 118: 1734-1738.

9. Naimi TS, Lipscomb LE, Brewer RD, Gilbert BC. Binge drinking in the preconception period and the risk of unintended pregnancy: implications for women and their children. Pediatrics 2003;111:1136-1141.

10. Koren G, Nulman I, Chudley AE, Loocke C. Fetal alcohol spectrum disorder. CMAJ 2003;169:1181-1185.

11. Weber MK, Floyd RL, Riley EP, Snider DE Jr. National Task Force on fetal alcohol syndrome and fetal alcohol effect. MMWR: Recomm Rep 2002;51:9-12.

12. Burd L, Wilson H. Fetal, infant, and child mortality in a context of alcohol use. Am J Med Genet C Semin Med Genet 2004;127:51-58

13. Kaup ZOL, Merighi MAB, Tsunechiro MA. Avaliação do consumo de bebida alcoólica durante a gravidez. Rev Ginecol Obstetr 2001;23:575-580. 
14. Adams J, Bittner P, Buttar HS, et al. Statement of the Public Affairs Committee of the Teratology Society on the fetal alcohol syndrome. Teratology 2002;66:344-347.

15. Kvigne VL, Leonardson GR, Brozelleca J, Brock E, Neff-Smith M, Welty TK. Characteristics of mothers who have children with fetal alcohol syndrome or some characteristics of fetal alcohol syndrome. J Am Board Fam Pract 2003;16:296-303.

16. Freire TM, Machado JC, Melo EV, Melo DG. Efeitos do consumo de bebida alcoólica sobre o feto. Rev Bras Ginecol Obstetr 2005;27:376-381.

17. Chen WJ, Maier SE, Parnell SE, West JR. Alcohol and the developing brain: neuroanatomical studies. Alcohol Res Health 2003;27:174-180.

18. Spohr HL, Willms J, Steinhausen HC. Fetal alcohol spectrum disorders in young adulthood. J Pediatr 2007;150:175-179.

19. Momino W, Sanseverino MTV, Schüler-Faccini L. Prenatal alcohol exposure as a risk factor for dysfunctional behaviors: the role of the pediatrician. J Pediatr (Rio J) 2008;84(4 Suppl):S76-S79.

20. Stoler JM, Holmes LB. Recognition of facial features of fetal alcohol syndrome in the newborn. Am J Med Genet C Semin Med Genet 2004;127:21-27.

21. Vasconcelos MM. Utilidade da espectroscopia por ressonância magnética no diagnóstico do transtorno do déficit de atenção/hiperatividade. Tese (Doutorado em Neurologia) - Universidade Federal Fluminense, Niterói. 2005.

22. Vasconcelos MM, Brito AR, Domingues RC, et al. Proton magnetic resonance spectroscopy in school-aged autistic children. J Neuroimaging 2008;18:288-295.

23. Mattson SN, Riley EP, Sowell ER, Jernigan TL, Sobel DF, Jones $\mathrm{KL}$. A decrease in the size of the basal ganglia in children with fetal alcohol syndrome. Alcohol Clin Exp Res 1996;20:1088-1093.
24. Watari H, Born DE, Gleason CA. Effects of first trimester binge alcohol exposure on developing white matter in fetal sheep. Pediatr Res 2006;59:560-564.

25. Roebuck TM, Mattson SN, Riley EP. A review of the neuroanatomical findings in children with fetal alcohol syndrome or prenatal exposure to alcohol. Alcohol Clin Exp Res 1998;22: 339-344.

26. Sowell ER, Thompson PM, Peterson BS, et al. Mapping cortical gray matter asymmetry patterns in adolescents with heavy prenatal alcohol exposure. Neuroimage 2002;17:1807-1819.

27. Riley EP, McGee CL, Sowell ER. Teratogenic effects of alcohol: a decade of brain imaging. Am J Med Genet C Semin Med Genet 2004;127:35-41.

28. Astley SJ, Weinberger E, Shaw DW, Richards TL, Clarren SK. Magnetic resonance imaging and spectroscopy in fetal ethanol exposed Macaca nemestrina. Neurotoxicol Teratol 1995;17: 523-530.

29. Cortese BM, Moore GJ, Bailey BA, Jacobson SW, Delaney-Black $\mathrm{V}$, Hannigan JH. Magnetic resonance and spectroscopic imaging in prenatal alcohol-exposed children: preliminary findings in the caudate nucleus. Neurotoxicol Teratol 2006;28:597-606.

30. Fagerlund A, Heikkinen S, Autti-Rämö I, et al. Brain metabolic alterations in adolescents and young adults with fetal alcohol spectrum disorders. Alcohol Clin Exp Res 2006;30:2097-2104.

31. Brandão LA, Domingues RC. Introdução e técnica. In: Brandão LA, Domingues RC. Espectroscopia de prótons do encéfalo: princípios e aplicações. Rio de Janeiro: Revinter 2002:1-14.

32. Ajilore O, Haroon E, Kumaran S, et al. Measurement of brain metabolites in patients with type 2 diabetes and major depression using proton magnetic resonance spectroscopy. Neuropsychopharmacology 2007;32:1224-1231. 